Annals of Warsaw University of Life Sciences - SGGW

Land Reclamation No 48 (1), 2016: 27-40

(Ann. Warsaw Univ. Life Sci. - SGGW, Land Reclam. 48 (1), 2016)

\title{
Analysis of rainfall-induced shallow landslides in Jamne and Jaszcze stream valleys (Polish Carpathians) - preliminary results
}

\author{
TYMOTEUSZ ZYDROŃ ${ }^{1}$, ANNA BUCAŁA ${ }^{2}$, PIOTR DEMCZUK ${ }^{3}$, \\ ANDRZEJ GRUCHOT ${ }^{1}$ \\ ${ }^{1}$ Department of Hydraulic Engineering and Geotechnics, University of Agriculture in Krakow \\ ${ }^{2}$ Department of Geoenviromental Research, Institute of Geography and Spatial Organization PAS \\ ${ }^{3}$ Department of Geomorphology, Maria Curie-Skłodowska University
}

\begin{abstract}
Analysis of rainfall-induced shallow landslides in Jamne and Jaszcze stream valleys (Polish Carpathians) - preliminary results. Preliminary shallow landslide susceptibility mapping of the Jamne and Jaszcze stream valleys, located in the Polish Flysch Carpathians, is presented in the paper. For the purpose of mapping, there were used SINMAP and Iverson's models integrating infiltration and slope stability calculations. The calibration of the used models parameters, obtained from limited field and laboratory tests, was performed using data from 8-9 July 1997, when as a consequence of a very intense rainfall, 94 shallow landslides were observed on meadows and arable lands. A comparison of the slope stability calculation results and the localisation of the noticed shallow landslides showed satisfactory agreement between localisation of the observed and computed unstable areas. However, it was concluded that better simulation results were obtained using Iverson's model.
\end{abstract}

Key words: landslides, GIS, the Flysch Carpathians, the Gorce Mountains

\section{INTRODUCTION}

Rainfall-induced shallow landslides are common phenomena in the world. They usually occur in tropical regions (e.g. Au 1998, Rao 1998, Fuchu et al. 1999, Liao et al. 2012), but they happen in moderate climate regions as well. Shallow movements are also noticed in the Polish Car- pathians area, where catastrophic rainfalls periodically take place (Jakubowski 1965, Ziętara 1968, Dziewański et al. 2003, Gorczyca 2004).

Prediction of the landslide occurrence is very important from an economic point of view. Generally, landslide susceptibility assessment methods can be classified into qualitative and quantitative. The first group of methods considers a statistical relationship between landslide occurrence and related factors (slope inclination, soil type, type of cover etc.), but not the failure mechanism (Park et al. 2013). So quantitative methods, based on physical or physically approximated models, which consider a cause-and-effect relationship between physical and instability processes, seem to be a better tool for the slope stability calculations. These methods are commonly used for the slope stability mapping by geologists, but they are not very often used for the mapping of the Polish Carpathians.

The preliminary landslide susceptibility mapping of slopes of the Jamne and Jaszcze stream valleys (the Gorce Mountains) done using two quantitative models is the subject of this paper. 


\section{STUDY AREA}

The Gorce, medium-sized mountains (600-1,300 $\mathrm{m}$ a.s.1.), are situated in the Polish Flysch Carpathians. They extend $33 \mathrm{~km}$ from west to east and form wide mountain ridges with steep slopes, deeply cut through by tributaries of the Raba and Dunajec rivers. The research was carried out in the valleys of the Jaszcze and Jamne streams (Ochotnica Dolna commune) - Figure 1.

Both catchments are in the range of the Magura nappe (Upper Cretaceosus to Eocene), which appear in the form of alternate sandstone and shale layers of varying thickness. Shales and thin bedded sandstones are less resistant to weathering, while more resistant thick beds of sandstone usually form the culminations (Sikora and Żytko 1968, Bur$\tan$ et al. 1978). The ridges are rounded and inclined up to $5^{\circ}$, but over $70 \%$ of the area occupies slopes steeper than $15^{\circ}$, of convex or convex-concave shape. Steep slopes are dissected by linear erosion and shaped mainly by shallow landslides, which cover about $10 \%$ of both catch-

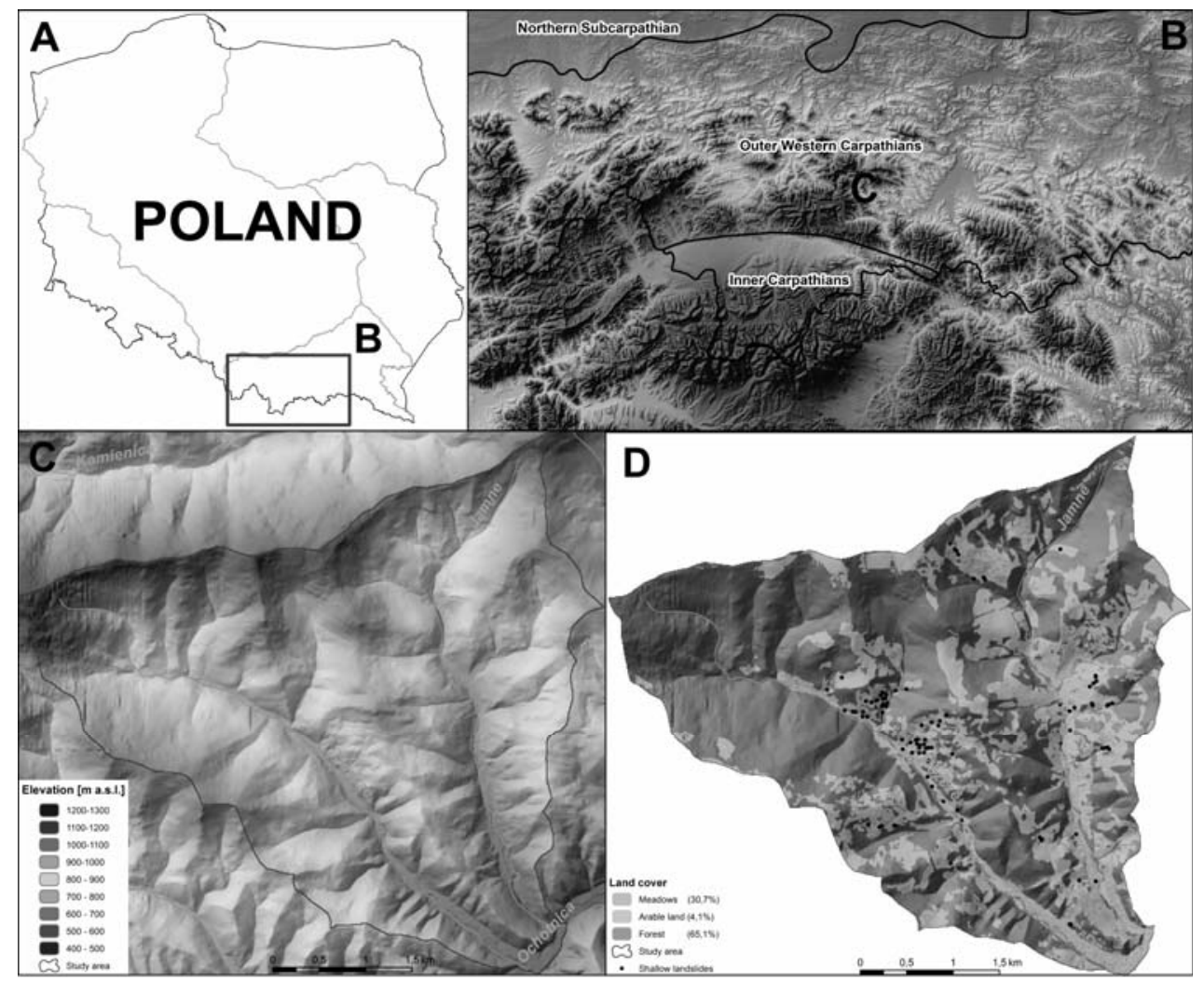

FIGURE 1. Location of the study area: (A) in relation to the area of Poland, (B) in relation to the Polish Carpathians Flysch, (C) Digital elevation model of the study area, (D) map of the land cover 
ments (Gerlach and Niemirowski 1968). The grain-size composition of these soils includes loams and sandy clay. In the Jaszcze and Jamne catchments, the soil layer is firmly attached to the parental rock, which is reflected in its physical and chemical properties and in the thickness of soil profiles. On the steep slopes, the soil profile thickness is diversified. In the upper parts of slopes, mainly shallow and moderately deep soils occur, and the thickness of profiles amounts to between 20 and $50 \mathrm{~cm}$ (Adamczyk and Komornicki 1969). In the lower parts of slopes, the thickness can exceed $1.5 \mathrm{~m}$. Additionally, there are rock fragments of parent material of various sizes in the profiles. These are chiefly fragments of sandstones.

Both drainage basins are overgrown with the forest of the lower montane zone, and the Carpathian spruce forest occurs only at elevations above $1,000 \mathrm{~m}$. The upper parts of the valleys are within the borders of the Gorce National Park (GNP), established in 1981. In both catchments, the effects of many centuries of human activities have transformed the natural environment. Current land use of the analyzed area is presented in Figure 1.

In the periods of July 1997 and July 2008 , very intense precipitation occurred in the study area. It was 70 and $76.3 \mathrm{~mm}$ respectively and triggered a number of landslides that were mostly shallow failures (Bucała 2012) (Fig. 1). A majority of them were classified as shallow debris flows of gravelly and sandy material. Some of them were translational landslides displaced along contact of slope covers and bedrock contact or rotational slides occurring within slope cover. The depth of slipping surfaces didn't exceed $1.5 \mathrm{~m}$.

\section{MATERIAL AND METHODS}

\section{Soil Parameters}

The research started with field and laboratory tests for determination of geotechnical parameters of soils. The samples were collected from a few sites located in the neighbourhood of the shallow landslides formed in 1997 and 2008. Depth of bedrock was estimated based on the observation of the outcrop of flysch strata in excavations made during road earthworks and in a few open pits made on the slopes of the Jamne catchment area (Bucała 2012).

Site investigations included making a few open pits in order to collect soil samples, determination of soil density using sand replacement method and estimation of hydraulic parameters of the soil. The laboratory tests comprised determination of a grain-size distribution, soil consistency limits and shear strength parameters. Shear strength tests were carried out in a standard direct shear apparatus. Some shear strength tests were also done in a triaxial apparatus using back-pressure method. 


\section{Models}

In order to determine slope stability conditions in both catchment areas, integrated calculations of infiltration and stability in GIS environment were carried out. For that purpose, there were two computational models used.

The first model describing landslide susceptibility of slopes is SINMAP (Stability INdex MAPping) model (Pack et al. 1999), which is commonly used for a slope stability analysis (Morrisey et al. 2001, Deb and El-Kadi 2009) mainly because it is simple and it is quite easy to define input parameters. The model integrates calculations of a steady subsurface flow induced by steady rainfall and slope stability calculations using a one-dimensional infinite slope stability model. The fundamental form of equation for determination of safety factor is given by:

$$
\begin{aligned}
& w=\frac{D_{w}}{D} \\
& r=\frac{\rho_{w}}{\rho} \\
& C=\frac{c_{r}+c_{s}}{D \cdot \cos \alpha \cdot \rho \cdot \mathrm{g}}
\end{aligned}
$$

and integrating of equations (1)-(4), the formula for the factor of safety is simplyfed to the following form:

$$
F S=\frac{C+\cos \alpha \cdot[1-\min (w ; 1) \cdot r] \cdot \tan \phi^{\prime}}{\sin \alpha}
$$

where:

$C$-dimensionless cohesion component

$$
C=\left(c_{r}+c_{s}\right) /\left(h \cdot \rho_{s} \cdot g\right),
$$

$c_{r}$ - root cohesion,

$c_{s}$ - soil cohesion,

$h$ - soil thickness,

$\rho_{s}$ - soil density,

$$
F S=\frac{c_{r}+c_{s}+\cos ^{2} \beta \cdot\left[\rho_{s} \cdot \mathrm{g} \cdot\left(D-D_{w}\right)+\left(\rho_{s} \cdot \mathrm{g}-\rho_{w} \cdot \mathrm{g}\right) \cdot D_{w}\right] \cdot \tan \phi^{\prime}}{D \cdot \rho_{s} \cdot \mathrm{g} \cdot \sin \beta \cdot \cos \beta}
$$

where:

$c_{r}$ - root cohesion,

$c_{s}$ - soil cohesion,

$\beta$ - slope inclination

$D$ - vertical soil depth,

$D_{w}$ - the vertical height of the water table,

g - gravitational acceleration,

$\rho_{s}$ - density of soil,

$\rho_{w}$ - water density,

$\varphi^{\prime}$ - effective angle of internal friction.

Assuming that: g - gravitational acceleration,

$\alpha$ - slope angle,

$\varphi^{\prime}-$ effective angle of internal friction,

$c^{\prime}$ - effective cohesion,

$w$ - wetness index $w=(R \cdot a) /(\mathrm{D} \cdot \mathrm{k} \cdot \sin \alpha \cdot \cos \alpha)$,

$k$ - coefficient of soil permeability,

$R$ - rain intensity,

$a$ - specific catchment area.

Equation (5) allows us to determine influence of subsurface flow, which acti- 
vates increase of perched groundwater, on changes of effective stresses within soil and in consequence decline in value of safety factor. In other words, the model assumes that rainfall causes partial saturation of superficial soil layer of
$(S I)$, that expresses probability that the factor of stability is higher than 1 . There are six distinguished six classes of SI, which are described in Table 1.

The second quantitative model used for mapping the landslide susceptible

TABLE 1. Stability class definitions in SINMAP (SINMAP user's manual)

\begin{tabular}{|c|c|c|l|l|}
\hline Class & SI & FS & \multicolumn{1}{|c|}{ Predicted state } & \multicolumn{1}{|c|}{ Parameter range } \\
\hline 1 & SI $>1.5$ & $F S_{\min }>1.5$ & stable slope zone & $\begin{array}{l}\text { range cannot model } \\
\text { instability }\end{array}$ \\
\hline 2 & $1.5>S I>1.25$ & $1.25<F S_{\min }<1.5$ & moderately stable zone & $\begin{array}{l}\text { range cannot model } \\
\text { instability }\end{array}$ \\
\hline 3 & $1.25>S I>1$ & $1<F S_{\min }<1.25$ & quasi-stable slope zone & $\begin{array}{l}\text { range cannot model } \\
\text { instability }\end{array}$ \\
\hline 4 & $1>S I>0.5$ & $F S_{\min }<1$ & $\begin{array}{l}\text { lower threshold slope } \\
\text { zone }\end{array}$ & $\begin{array}{l}\text { pessimistic half of range } \\
\text { required for instability }\end{array}$ \\
\hline 5 & $0.5>S I>0$ & $F S_{\min }<1$ & $\begin{array}{l}\text { upper threshold slope } \\
\text { zone }\end{array}$ & $\begin{array}{l}\text { optimistic half of range } \\
\text { required for stability }\end{array}$ \\
\hline 6 & $0>S I$ & $F S_{\max }<1$ & defended slope zone & $\begin{array}{l}\text { range cannot model } \\
\text { stability }\end{array}$ \\
\hline
\end{tabular}

slope, what has an effect on increase of wetness index values and in consequence has the influence on numerator of equation (5). The variables $a, \alpha$ derive from digital elevation model (DEM), whereas $C, \varphi$ ' and $T$ are input by the user and they can vary in some boundaries. Thus, slope

$$
\psi(z, t \leq T)=(z-d) \cdot \cos ^{2} \beta+\frac{J}{k_{s}}\left[\left(\frac{4 \cdot D \cdot \cos ^{2} \beta \cdot t}{\pi}\right)^{1 / 2} \cdot \exp \left(-\frac{z}{4 \cdot D \cdot \cos ^{2} \beta \cdot t}\right)-z \cdot \operatorname{erfc}\left(\frac{z^{2}}{4 \cdot D \cdot \cos ^{2} \beta \cdot t}\right)^{1 / 2}\right]
$$

stability calculations are made considering different values of input geotechnical parameters of soil. As a result, the SINMAP represents a probabilistic approach to the slope stability analysis, which is described by the value of Stability Index areas was Iverson's model (2000), which uses a physical model of rainwater infiltration in the soil profile described by the linearized one-dimensional Richard's equation. The slope stability changes are mainly a results of pore water pressure changes, which are expressed by the following equations:

where:

$z$ - depth,

$t$ - time,

$T$ - rainfall duration,

$d$ - depth of groundwater table,

$D$ - effective hydraulic diffusivity expressed by 


$$
\begin{aligned}
& \psi(z, t>T)=\psi(z, t \leq T)+ \\
& +\frac{J}{k_{s}}\left[\left(\frac{4 \cdot D \cdot \cos ^{2} \beta \cdot(t-T)}{\pi}\right)^{1 / 2} \cdot \exp \left(-\frac{z}{4 \cdot D \cdot \cos ^{2} \beta \cdot(t-T)}\right)-z \cdot \operatorname{erfc}\left(\frac{z^{2}}{4 \cdot D \cdot \cos ^{2} \beta \cdot(t-T)}\right)^{1 / 2}\right]
\end{aligned}
$$

$C_{0}$ - minimum value of the change in volumetric content per unit change in pressure:

$$
D=4 \cdot D_{0} \cdot \cos ^{2} \beta=4 \cdot \frac{k_{s}}{C_{0}} \cdot \cos ^{2} \beta
$$

$\operatorname{erfc}$ - complementary error function.

In Iverson's model, as Morrisey et al. (2001) point out, the pore water pressure is calculated considering vertical flow, and not slope parallel flow as in SINMAP, in the unsaturated zone above the groundwater table as well as in the saturated zone below the water table. As a result of the pore water pressure changes, the factor of safety can be determined using the following formula:

$$
F S=\frac{\operatorname{tg} \phi^{\prime}}{\operatorname{tg} \beta}+\frac{c^{\prime}-\gamma_{w} \cdot \psi(z, t) \cdot \operatorname{tg} \phi^{\prime}}{\gamma \cdot z \cdot \sin \beta \cdot \cos \beta}
$$

In equation (8), soil suction is considered as a negative pore water pressure. An advantage of Iverson's model is that slope stability calculations can be made for transient rainfall. In such case the analysis is divided into periods, in which uniform rainfall intensities are considered. For each analytic period are calculated changes of pore water pressure and safety factor values. As indicate Baum et al. (2008) applicability of the model is limited to the homogeneous isotropic soil condition and the model is not recommended for using for the slopes steeper than $60^{\circ}$.

For the purpose of the analysis, equations (6) and (7) were used, which were adapted to the calculation of an unsteady infiltration. Their modification was based on the change of the second element of the equation, where in every calculation step rainfall intensity values were used separately. The value of the hydraulic diffusivity was estimated on the basis of a Soil Water Characteristic Curve (SWCC), which was determined on the basis of the geotechnical parameters of the soil (void ratio, grain-size distribution, liquid limit) using a model of Aubertin et al. (2003). Groundwater table was assumed to be at $1 \mathrm{~m}$ below the surface, which was close to the average depth of sliding surfaces of the observed landslides. Criterion of shallow landslide susceptibility was assumed according to the obtained values of the safety factor:

- FS $<1$ - high probability of landslide,

- $1<F S<1.3$ - probable instability,

- $1.3<F S<1.5$ - low probability of landslide,

- $F S>1.5$ - very low probability of landslide.

For the purpose of mapping, Digital Elevation Model (DEM) was prepared 
with the resolution of $10 \mathrm{~m}$, which is the maximum value recommended by Morrisey et al. (2001). The model was done on the basis of a digital terrain model derived from the Geodetic and Carthographic Documentation Centre (CODGiK).

For analysis executed using SINMAP the amount of precipitation was assumed as daily rainfall (equal to $70 \mathrm{~mm}$ ) recorded in 8 July 1997 at the weather station of Institute of Meteorology and Water Management in Ochotnica Górna. Because of the small area of analyzed catchments we assumed that the amount of precipitation was uniform for all tested areas. For analysis using Iverson's model were used hourly rainfall data from the period of 7-9 July 1997 published by Grela et al. (1999). Landslide susceptibility areas obtained from the slope stability calculations were com- pared to the areas of failures arisen in the above mentioned period.

Location of the landslides was interpreted using aerial photos; the area of analysis was limited to meadows and arable areas which comprise approximately $35 \%$ of the catchments area.

\section{RESULTS AND DISCUSSION \\ Geotechnical parameters of slope covers}

Generally, slope covers of both catchments are composed of coarse-grained soils, which according to the Polish standard [PN-EN ISO 14668-2:2004] were classified as sandy clayey gravel (saclGr) of medium permeability - Table 2 .

Shear strength test results (Table 3) revealed that the tested soils had great values of the angle of internal friction. Values of cohesion were in the range

TABLE 2. Geotechnical parameters of the soils from the Jamne and Jaszcze stream valleys

\begin{tabular}{|c|c|c|}
\hline Parameter & Range of values & Mean value \\
\hline $\begin{array}{l}\text { Fraction content [\%] } \\
\text { cobbles }(63-200 \mathrm{~mm})\end{array}$ & $0.0-17.1$ & 7.11 \\
\hline gravel $(2-63 \mathrm{~mm})$ & $16.9-41.0$ & 28.4 \\
\hline sand $(0.063-2 \mathrm{~mm})$ & $14.4-54.1$ & 32.1 \\
\hline silt $(0.002-0.063 \mathrm{~mm})$ & $18.5-38.2$ & 23.4 \\
\hline clay $(<0.002 \mathrm{~mm})$ & $7.0-15.4$ & 9.0 \\
\hline Type acc. to PN-EN ISO 14668-2:2004 & clSa, saclGr & saclGr \\
\hline Density $\left[\mathrm{g} \cdot \mathrm{cm}^{-3}\right]$ & $1.51-1.92$ & 1.82 \\
\hline Natural moisture content [\%] & $11.2-25.8$ & 19.6 \\
\hline Dry density $\left[\mathrm{g} \cdot \mathrm{cm}^{-3}\right]$ & $1.35-1.72$ & 1.51 \\
\hline $\begin{array}{l}\text { Atterberg's limits [\%]* } \\
\text { plasticity limit } \\
\text { liquid limit }\end{array}$ & $\begin{array}{l}14.0-23.2 \\
23.8-35.4\end{array}$ & $\begin{array}{l}19.5 \\
31.9\end{array}$ \\
\hline Plasticity index [\%] & $9.8-14.3$ & 12.5 \\
\hline Coefficient of permeability $\left[\mathrm{m} \cdot \mathrm{s}^{-1}\right]$ & $1.3-3.6 \cdot 10^{-5}$ & $2.9 \cdot 10^{-5}$ \\
\hline
\end{tabular}

* For particles smaller than $2 \mathrm{~mm}$. 
TABLE 3. Shear strength test results

\begin{tabular}{|c|c|c|c|c|c|}
\hline \multirow{3}{*}{ Test method } & \multirow{3}{*}{ Failure criterion } & \multicolumn{2}{|c|}{ Range of values } & \multicolumn{2}{|c|}{ Mean value } \\
\hline & & $\begin{array}{l}\text { angle of } \\
\text { internal } \\
\text { friction }\end{array}$ & cohesion & $\begin{array}{l}\text { angle of } \\
\text { internal } \\
\text { friction } \\
\end{array}$ & cohesion \\
\hline & & $\circ$ & $\mathrm{kPa}$ & $\circ$ & $\mathrm{kPa}$ \\
\hline \multirow{3}{*}{$\begin{array}{l}\text { Traxial } \\
\text { apparatus }\end{array}$} & $\begin{array}{l}\text { horizontal displacement } \\
10 \%\end{array}$ & $29.7-34.9$ & $3.2-9.6$ & 32.3 & 6.4 \\
\hline & $\begin{array}{l}\text { horizontal displacement } \\
20 \%\end{array}$ & $28.5-34.2$ & $5.1-11.8$ & 31.4 & 8.5 \\
\hline & $\max \left(\sigma_{1}-\sigma_{3}\right)$ & $30.0-34.4$ & $4.9-9.7$ & 32.2 & 7.3 \\
\hline $\begin{array}{l}\text { Direct } \\
\text { shear-box }\end{array}$ & $\begin{array}{l}\text { max value of shear } \\
\text { strength }\end{array}$ & $28.2-32.1$ & $6.0-9.8$ & 30.4 & 7.7 \\
\hline
\end{tabular}

from 3.7 to $11.8 \mathrm{kPa}$, which is not typical for these types of soils. It was stated that such great values of cohesion are connected with the grain-size distribution of the tested soil samples. Therefore, for the purpose of the slope stability analysis, the value of cohesion was reduced. Parameters used as an input data in SINMAP were diversified due to the land use (Table 4). In case of Iverson's model input shear strength parameters were: angle of internal friction $34.9^{\circ}$ and cohesion $1.6 \mathrm{kPa}$. Permeability coefficients had the same values as a minimum values of these parameters used in case of analysis using SINMAP model.

\section{Slope stability calculations}

The results of the slope stability analysis (Fig. 2b) revealed that over $70 \%$ of the whole catchments area is susceptible to shallow landslides, which is connected mainly with the steep inclination of slopes. However, it should be noted that most of the area was classified as upper threshold zone, which means that only the worst values of shear strength parameters give values of safety factor smaller than 1 . The results of hydrological calculations (Fig. 2a) revealed that the rainfall of the assumed intensity can saturate the slope cover. Next, the results of the slope stability calculations made

TABLE 4. Initial setting of SINMAP

\begin{tabular}{|l|c|c|c|c|c|c|c|c|c|c|}
\hline \multirow{2}{*}{ Land use } & Soil depth & Bulk density & $k_{s \min }$ & $k_{s \max }$ & $C_{\min }$ & $C_{\max }$ & $\varphi_{\min }$ & $\varphi_{\max }$ & $\begin{array}{c}T / R \\
\min \end{array}$ & $\begin{array}{c}T / R \\
\max \end{array}$ \\
\cline { 2 - 12 } & $\mathrm{m}$ & $\mathrm{kg} \cdot \mathrm{m}^{-3}$ & $\mathrm{~m} \cdot \mathrm{s}^{-1}$ & $\mathrm{~m} \cdot \mathrm{s}^{-1}$ & - & - & $\circ$ & $\circ$ & $\mathrm{m}$ & $\mathrm{m}$ \\
\hline Meadows & 1 & 1900 & $1 \cdot 10^{-5}$ & $1 \cdot 10^{-4}$ & 0 & 4.8 & 28.5 & 34.9 & 11 & 114 \\
\hline Forest & 1 & 1900 & $2 \cdot 10^{-5}$ & $2 \cdot 10^{-4}$ & 0 & 6.4 & 28.5 & 34.9 & 23 & 227 \\
\hline Arable land & 1 & 1900 & $2 \cdot 10^{-5}$ & $2 \cdot 10^{-4}$ & 0 & 4.8 & 28.5 & 34.9 & 23 & 227 \\
\hline
\end{tabular}




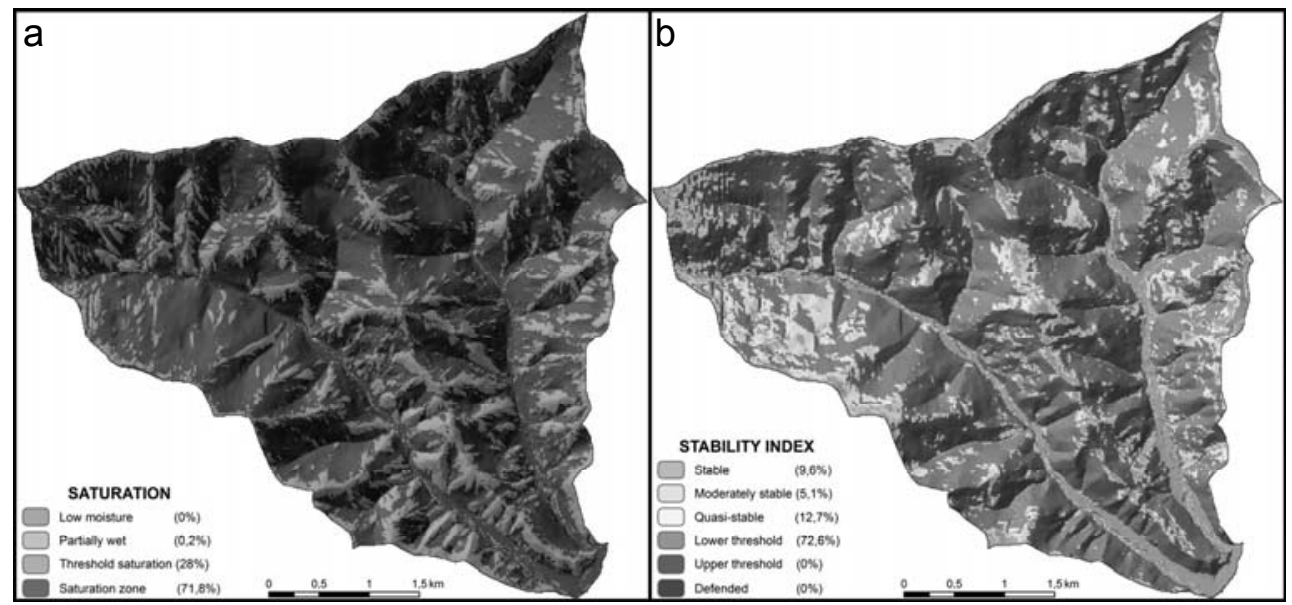

FIGURE 2. Degree of saturation (a) and slope stability index (b) maps from the simulation obtained by SINMAP

for meadows and arable lands showed that $61.4 \%$ of the area were indicated as lower-threshold, $15.6 \%$ as quasi-stable, $6.6 \%$ as moderately stable and $16.4 \%$ as stable zone.

Slope stability calculations using Iverson's transient diffusive model were made for the period of 8-9 July 1997 when a catastrophic $158 \mathrm{~mm}$ rainfall occurred. Simulation results (Fig. 3) revealed that the critical periods for the slope stability conditions occurred at the end of the analysis, when the most intense precipitation took place. The calculations results obtained in the last period indicate that the $7.2 \%$ of the whole Jamne and Jaszcze catchment areas are classified as unstable, $26.7 \%$ as quasi-stable. However, the slope stability simulation limited to meadows and arable lands showed that the zone prone to shallow landslides comprises $37.3 \%$ of the analysed region, and for only $11.1 \%$ of the region stability factors are less than 1 .

Comparative analysis of the slope stability calculations using two physically-based models revealed some differences between the observed landslides and landslide prone areas indicated by models. As notice Crosta and Frattini (2003), sources of errors in the slope stability modelling can be classified into two types: computed stable grids are located in an actually unstable area and computed unstable grids are located in a stable zone. The results of the simulation using SINMAP revealed that $77 \%$ (72 from 94) of the observed landslides were correctly localised in the unstable area $(S I<1), 20 \%$ were localised in the quasi-stable area and $4 \%$ of the landslides were indicated in the stable zone. Next, results of the modelling using Iverson's model showed that $35.1 \%$ of the observed landslides were correctly lo- 


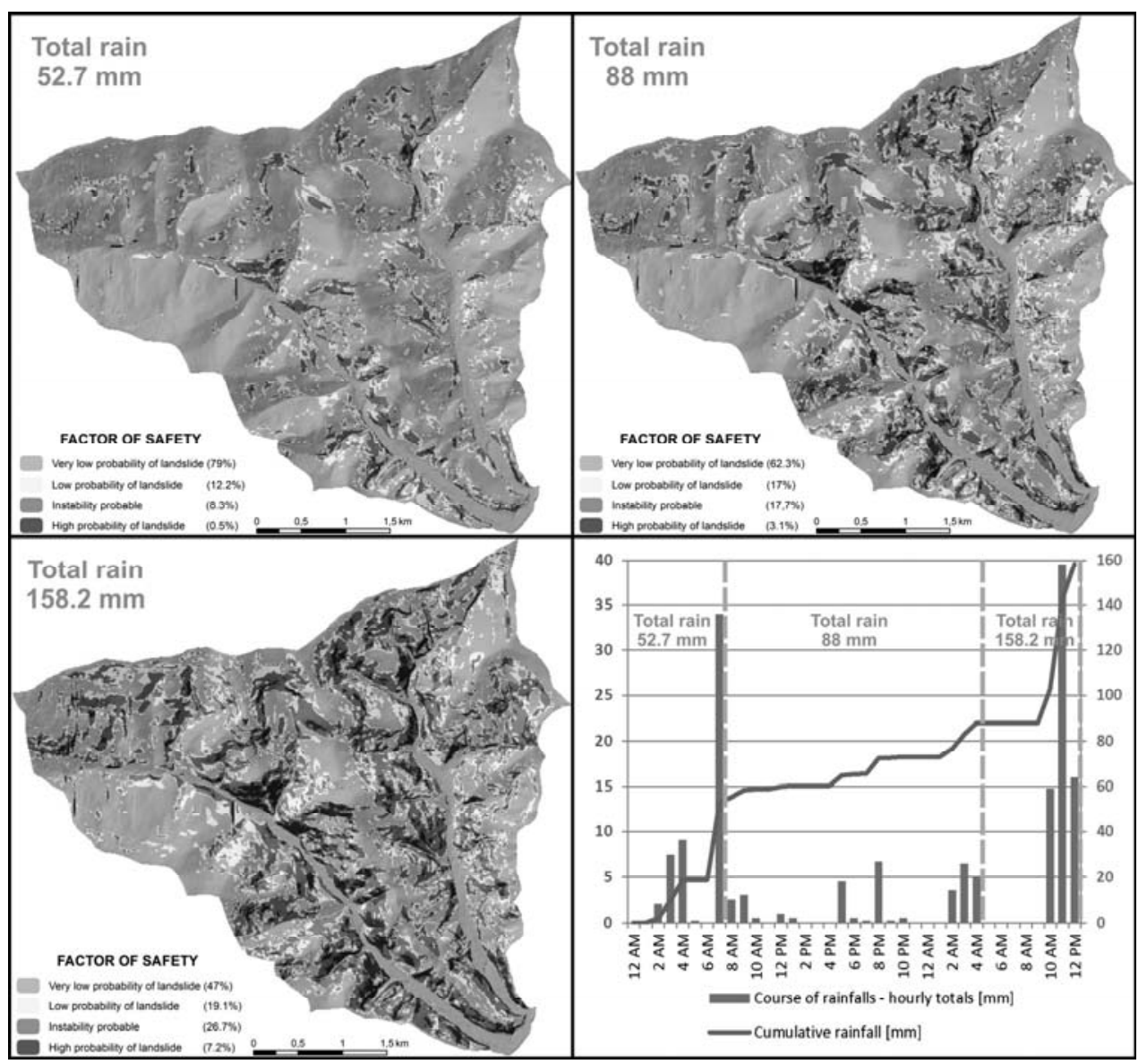

FIGURE 3. Slope stability map obtained by the simulation according to Iverson's model for different periods during the rainfall of 8-9 July 1997

calised in the unstable area $(F S<1)$ and $34.0 \%$ were localised in the area, where the probability of failure was quite high $(1.01<F S<1.30)$. It means that higher amounts of the correctly localised landslides were determined using SINMAP. However, the percentage of the areas prone to landslides for meadows and arable lands in the analysed catchments modelled by SINMAP was over $60 \%$ of the area, whereas calculation using
Iverson's model revealed that the areas susceptible to shallow mass-movements comprise $37.3 \%$ of the catchments area. Hence, comparing simulation results for both models one can state that the SINMAP overestimates unstable areas, which was also pointed out by Morrisey et al. (2001), Crosta and Frattini (2003) or Zizioli et al. (2013).

For the purpose of a quantitative comparison of modelling results, a Qual- 
ity Index proposed by Crosta and Frattini (2003) was used in a further part of the work. The index defines ratio of the landslide's area within stable and unstable areas. The results of the calculations revealed that the Quality Index obtained for Iverson's model was significantly greater (3.8) than the one determined using SINMAP (2.1). These values are not very great in comparison to the results obtained by Crosta and Frattini (2003). It means that the models of the Jamne and Jaszcze catchments need corrections. A source of the discrepancies between the actual landslide and the results of modelling can be due to errors within hydrological or stability models of slopes. Crosta and Frattini (2003) suggest that hydrological model errors can be a result of e.g. an incorrect rainfall input, wrong hydrological parameters, violation of model assumptions and overestimation of hydrological processes. A few permeability tests revealed that hydraulic conductivities of slope cover are not very diverse. Hydrological calculations obtained for both models gave the same qualitative results, indicating that the-analysed rainfall was deep enough to saturate the soil profile and induce seepage forces within the slopes.

On the other hand the stability model errors can be related to incorrectly determined soil properties, uncertain description of the morphology and lithology of the area. In both models, geotechnical parameters of soil were assumed based on the limited amount of tests and they were very similar. The main discrepancy of the parameters assumed for the calculations in both models was connected with cohesion. In SINMAP the minimum value of cohesion was equal $0 \mathrm{kPa}$, whereas in Iverson's model it was assumed as equal to $1.6 \mathrm{kPa}$. As Deb and El-Kadi (2009) point out, the cohesion component has a significant influence on the stability calculations, which can explain, why unstable areas indicated by SINMAP were larger than the ones obtained using Iverson's model.

Other important factors, which have a significant influence on the hydrological as well as stability analysis results, are correct determination of the initial ground water level and the thickness of the slope cover. In the model, due to the lack of detailed field data, a uniform soil thickness was assumed. As indicates Ho et al. (2012) calculation results, such assumption can cause an overestimation as well as underestimation of the amount of unstable grids. The ground water table level was assumed as equal to the soil thickness, which was also equal to the depth of the bedrock. On the basis of field observation, it was stated, that during the intense rainfall, water accumulated on the roof of the bedrock.

Another significant factor, which can trigger shallow landslides, is an erosion process of mountainous streams. Some shallow landslides, which were not computed by models, were localised in the 
vicinity of streams, which can erode during floods, cut the base of slopes and affect their failure. It's difficult to simulate this process due to the fact, that the local changes of the slopes inclination at river banks are usually too small to be visible in digital elevation models. The problem of the resolution of DEM was pointed out, among others, by Zizioli et al. (2013), who noticed significant discrepancies between observation and simulation of the slope stability results for linear engineering constructions as roads. They observed many shallow landslides in the vicinity of road embankments, which were usually not computed by model.

\section{CONCLUSIONS}

The preliminary shallow landslide susceptibility mapping of the Jamne and Jaszcze catchment areas using two quantitative (physically-based) models was the subject of this study. For the purpose of the research, limited permeability and shear strength tests were carried out and their results were used in the further part of the work for the slope stability modelling. Data collected at shallow landslides activated in the period of 8-9 July 1997 as a consequence of a very intense, short-lasting rainfall were used as the reference for the simulation results.

Comparative analysis of two selected models showed that the major factor controlling instability processes in the Jamne and Jaszcze catchments was the saturation of the slope cover, which induced seepage forces within the soil profile. The comparison of the slope stability results and the localisation of the noted shallow landslides showed close agreement between the localisation of the observed and computed unstable areas. Simulation results obtained using SINMAP revealed that $77 \%$ of the observed landslides were correctly localised, whereas Iverson's model indicated correctly $69 \%$ of landslides. However, it was stated that the SINMAP overestimates landslide prone areas. Therefore, estimation of accuracy of the model made using Quality Index revealed, that better simulation results were obtained using Iverson's model.

The analysis of the simulation results revealed that discrepancies of the observed and computed unstable areas location can be related to the limited site investigation and laboratory tests. So, further calibration of the tested model should be concentrated on detailed recognition of the geological structure of both analysed catchment areas and the analysis of fluvial processes within stream-channels.

\section{Acknowledgements}

The presented research was co-financed by the National Science Centre as a part of the grant NN 306659940.

Research was also supported by Ministry of Science and Higher Education, Republic of Poland (DS-3322/ /KIWiG/2015). 


\section{REFERENCES}

ADAMCZYK B., KOMORNICKI T. 1969: Charakterystyka gleboznawcza dolin potoków Jaszcze i Jamne. [The soils of Jaszcze and Jamne valleys]. Studia Naturae A, 3, 102-153 (Engl. summ).

AU S.W.C. 1998: Rain-induced slope instability in Hong Kong. Engineering Geology 51, $1-36$.

AUBERTIN M., MBONIMPA M., BUSSIČRE B., CHAPUIS R.P. 2003: A model to predict the water retention curve from basic geotechnical properties. Can. Geotech. J. 40 (6), 1104-1122.

BAUM R.L., SAVAGE W.Z., GODT J.W. 2008: TRIGRS - A Fortran Program for Transient Rainfall Infiltration and Grid-Based Regional Slope Stability Analysis. Version 2.0. USGS. Open-File Report. 2008-1159.

BUCAŁA A. 2012: Współczesne zmiany środowiska przyrodniczego dolin potoków Jaszcze i Jamne w Gorcach [Contemporary environmental changes of Jaszcze and Jamne stream valleys in the Gorce Mountains]. Prace Geograficzne IGiPZ PAN 231 [Engl. summ.].

BURTAN J., PAUL Z., WATYCHA L. 1978: Szczegółowa mapa geologiczna Polski 1: 50000 , arkusz Mszana Górna [Detailed Geological Map of Poland, 1: 50 000, sheet Mszana Górna]. PGI, Warszawa.

CROSTA G.B., FRATTINI P. 2003: Distributed modelling of shallow landslides triggered by intense rainfall. Nat. Hazards Earth Syst. Sci. 3, 81-93.

DEB SK., El-KADI A.I. 2009: Susceptibility assessment of shallow landslides on Oahu, Hawaii, under extreme-rainfall events. Geomorphology 108, 219-233.

DZIEWAŃSKI J., WOTA A.K., LIMANÓWKA D., CEBULAK E., MICHALIK S. 2003: Katastrofalny spływ wodno-gliniasty w Muszynie w lipcu 2002 roku [Catastrophic mud-flow (water-clay mass) in Muszyna in July 2002]. Wydawnictwo Instytutu Gospodarki Surowcami Mineralnymi i Energią PAN, Kraków (Engl. summ.).

FUCHU D., LEE CF., SIJING W. 1999: Analysis of rainstorm-induced slide-debris flows on natural terrain of Lantau Island, Hong Kong. Eng. Geol. 51, 279-290.

GERLACH T., NIEMIROWSKI M. 1968: Charakterystyka geomorfologiczna dolin Jaszcze i Jamne [Geomorphological description of the Jaszcze and Jamne] In: A. Medwecka-Kornaś (Ed), Doliny potoków Jaszcze i Jamne w Gorcach [The Jaszcze and Jamne stream valleys in the Gorce Mts.]. Studia Naturae A, 2, 11-22 (Engl. summ.).

GORCZYCA E. 2004: Przekształcanie stoków fliszowych przez procesy masowe podczas katastrofalnych opadów (dorzecze Łososiny) [The transformation of flysch slopes by catastropic rainfall-induced mass-processes (Łososina river catchment basin)]. Wyd. Uniwersytetu Jagielońskiego, Kraków (Engl. summ.).

GRELA J., SŁOTA H., ZIELIŃSKI J. (Eds). 1999: Dorzecze Wisły. Monografia powodzi lipiec 1997. IMiGW [Vistula River basin. Monograph floods in July 1997. IMiGW]. IMiGW, Warszawa (in Polish).

HO J.Y., LEE K.T., CHANG T.C., WANG Z.Y., LIAO Y.H. 2012: Influences of spatial distribution of soil thickness on shallow landslide prediction. Eng. Geol. 124, 38-46.

IVERSON R.M. 2000: Landslide triggering by rain infiltration. Water Resources Research 36 (7), 1897-1910.

JAKUBOWSKI K. 1965. Wpływ pokrycia roślinnego oraz opadów atmosferycznych na powstawanie osuwisk zwietrzelinowych [The influence of the vegetable cover and rainfalls on the formation of landslides]. Przeg. Geol. 13, 9, 395-398 (in Polish).

LIAO Z., HONG Y., KIRSCHBAUM D., LIU C. 2012: Assessment of shallow landslides from Hurricane Mitch in central America using a physically based model. Environ. Earth Sciences 66, 1697-1705.

MORRISSEY M.M., WIECZOREK G.F., MORGAN B.A. 2001: A Comparative Analysis of Hazard Models for Predicting Debris Flows in Madison County, Virginia. U.S. Geological Survey - Open-File Report 01-0067.

MORRISSEY M.M., WIECZOREK G.F., MORGAN B.A. 2008: A comparative analysis of simulated and observed landslide locations 
triggered by Hurricane Camille in Nelson County, Virginia. Hydrol. Processes 22, 524-531.

PACK R.T., TARBOTON D.G., GOODWIN C.N. 1999: GIS-based landslide susceptibility mapping with SINMAP. J.A. Bay (Ed.) Proceedings of the 34th Symposium on Engineering Geology and Geotechnical Engineering, Logan, Utah.

PARK H.J., LEE J.H., WOO I. 2013: Assesment of rainfall-induced shallow landslide susceptibility using a GIS-based probabilistic approach. Eng. Geol. 161, 1-15.

PN-EN ISO 14668-2:2004. Badania geotechniczne. Oznaczanie i klasyfikowanie gruntów. Część 2. Zasady klasyfikowania [Geotechnical investigation and testing - Identification and classification of soil. Part 2. Principles for a classification]. PKN, Warszawa (Engl. summ.).

RAO S.M. 1998: Role of apparent cohesion in the stability of Dominican allophane soil slopes. Engin. Geo. 43, 265-279.

SINMAP. User's manual. USGS.

SIKORA W., ŻYTKO K. 1968: Warunki geologiczne dolin Jaszcze i Jamne [The geology of the Jaszcze and Jamne valleys]. In: A. Medwecka-Kornaś (Ed.), Doliny potoków Jaszcze i Jamne w Gorcach. Gorcach [The Jaszcze and Jamne stream valleys in the Gorce Mts.]. Studia Naturae, A, 2, 23-38 (Engl. summ).

ZIĘTARA T. 1968: Rola gwałtownych ulew i powodzi w modelowaniu rzeźby Beskidów [The role of the heavy rainfalls and floods in modeling relief of Beskidy Mountains]. Prace Geograficzne Instytutu Geografii PAN 60, (in Polish).

ZIZIOLI D., MEISINA C., VALENTINO R., MONTRASIO L. 2013: Comparison between different approaches to modeling shallow landslide susceptibility: case history in Oltrepo Pavese. Northern Italy. Nat. Hazards Earth Syst. Sci. 13, 559-573.

Streszczenie: Analiza wplywu nawalnych opadów na powstawanie plytkich osuwisk $w$ dolinach potoków Jaszcze i Jamne (Polskie Karpaty) - wstępne wyniki badań. W pracy przedstawiono wstępne wyniki oceny podatności osuwiskowej powierzchniowych warstw zboczy dolin potoków
Jamne i Jaszcze, położonych w Gorcach (Karpaty Zewnętrzne). Do analiz wykorzystano dwa modele deterministyczne integrujące obliczenia infiltracji wód opadowych i stateczności: model SINMAP i Iversona. Dla określenia poprawności uzyskanych wyników obliczeń odniesiono je do wyników obserwacji terenowych przeprowadzonych w okresie 8-9 lipca 1997 roku, kiedy intensywne opady spowodowały intensyfikację ruchów masowych w zlewniach analizowanych potoków. W celu doboru parametrów geologiczno-inżynierskich na tym terenie wykonano terenowe pomiary wodoprzepuszczalności gruntów pokryw stokowych oraz oznaczono parametry wytrzymałości na ścinanie metodą bezpośredniego ścinania i trójosiowego ściskania. Analiza wyników obliczeń stateczności dały znaczące różnice uzyskanych wartości współczynników stateczności, przy czym wykazały one, że podstawowym czynnikiem sprzyjającym przekroczeniu granicznego stanu naprężeń jest nasycenie pokryw stokowych. Ogólnie lepsze dopasowanie wyników obliczeń do danych pomiarowych (wyników obserwacji terenowych) uzyskano, stosując model Iversona, model SINMAP spowodował natomiast przeszacowanie wielkości obszaru zagrożonego ruchami masowymi.

Stowa kluczowe: osuwiska, GIS, Karpaty Fliszowe, Gorce

\section{MS. received February 2016}

\section{Authors' address:}

Tymoteusz Zydroń, Andrzej Gruchot

Uniwersytet Rolniczy w Krakowie

Katedra Inżynierii Wodnej i Geotechniki

al. Mickiewicza 24/28, 30-059 Kraków, Poland

e-mail: tzydron@ar.krakow.pl rmgrucho@cyf-kr.edu.pl

Anna Bucała

Instytut Geografii i Przestrzennego

Zagospodarowania PAN

ul. Św. Jana 22, 31-018 Kraków, Poland

e-mail: abucala@zg.pan.krakow.pl

Piotr Demczuk

Uniwersytet Marii Curie-Skłodowskiej w Lublinie Wydział Nauk o Ziemi i Gospodarki Przestrzennej Zakład Geomorfologii al. Kraśnicka 2cd/209, 20-718 Lublin, Poland e-mail: demczuk@poczta.umcs.lublin.pl 